DOI: $10.19195 / 2084-5065.43 .12$

\title{
Osadzeni niebezpieczni. Procedura kwalifikacji, jej weryfikacja oraz zakres ograniczeń
}

\author{
Tomasz KaLISZ \\ Zakład Prawa Karnego Wykonawczego \\ Uniwersytet Wrocławski
}

I. Skazani oraz tymczasowo aresztowani, stwarzający poważne zagrożenie społeczne albo poważne zagrożenie bezpieczeństwa jednostek penitencjarnych stanowią szczególną grupę osób karnie izolowanych. Bardzo często są to osoby wykazujące znaczny stopień demoralizacji, agresywne, niebezpieczne dla społeczeństwa i współosadzonych. Zaliczamy do nich również osoby bezpośrednio zaangażowane, a niejednokrotnie pełniące funkcje kierownicze $\mathrm{w}$ ramach przestępczości zorganizowanej. W praktyce funkcjonowania systemów penitencjarnych osoby te stanowią realne zagrożenie prawidłowego funkcjonowania i bezpieczeństwa zakładów karnych. Przedmiotem szczegółowych rozważań niniejszego opracowania jest ocena przyjętych w 2015 r. nowych rozwiązań kodeksu karnego wykonawczego ${ }^{1}$, dotyczących procedury kwalifikowania do grupy osadzonych niebezpiecznych treści ograniczeń związanych z warunkami odbywania kary lub środka zapobiegawczego i możliwości ich indywidualnego kształtowania.

Budowany w ciągu ostatnich lat polski model postępowania $\mathrm{z}$ tą kategorią osadzonych wyraźnie zdominowany był przez funkcję izolacyjno-zabezpieczającą. Nie powinno to nas zbytnio zaskakiwać, choć w perspektywie standardów międzynarodowych ${ }^{2}$ oraz orzecznictwa Europejskiego Trybunału Praw Człowie-

1 Ustawa z dnia 10 września 2015 r. o zmianie ustawy — Kodeks karny wykonawczy (Dz.U. z 2015 r. poz. 1573).

2 Wzorcowe reguły minimalne Organizacji Narodów Zjednoczonych dotyczące postępowania z więźniami (Reguły Mandeli), 7 października 2015 r., https://www.rpo.gov.pl/sites/default/ files/Reguly_Mandeli.pdf(dostęp: 30.01.2017) oraz Europejskie Reguły Więzienne — Rekomendacja Rec (2006) 2. Komitetu Ministrów do państw członkowskich Rady Europy (przyjęta przez Ko- 
ka w Strasburgu (dalej ETPCz) $)^{3}$ wymusza potrzebę stałej weryfikacji rozwiązań normatywnych, a zwłaszcza istniejącej w tym zakresie praktyki ${ }^{4}$. W tak ujętej optyce ramą naszej oceny muszą być pytania o to, czy zachowany jest standard chroniący godność ludzką osadzonych, czy formy izolacji skazanych niebezpiecznych nie naruszają zakazu nieludzkiego i poniżającego karania, czy w warunkach daleko idącej izolacji możliwe jest prowadzenie oddziaływań penitencjarnych, jak kształtuje się wzajemna relacja między funkcją izolacyjną a funkcją związaną ze społeczną readaptacją oraz czy warunki odbywania kary w oddziałach dla osadzonych niebezpiecznych zawsze są adekwatne do zagrożeń płynących ze strony tych skazanych ${ }^{5}$.

II. Bardzo ważną przestrzenią do oceny rozwiązań normatywnych, a zwłaszcza praktyki funkcjonowania polskiego systemu penitencjarnego, są uwagi i oceny przedstawiane przez ETPCz w licznych orzeczeniach wywiedzionych w ramach skarg obywateli polskich na sposób ich traktowania jako tzw. osadzonych niebezpiecznych. W swoich orzeczeniach ETPCz podkreśla, że:

Nawet w najtrudniejszych okolicznościach, takich jak walka z terroryzmem lub przestępczością kryminalną, Konwencja zabrania kategorycznie tortur oraz nieludzkiego lub poniżającego traktowania albo karania bez względu na zachowanie ofiary — Piechowicz v. Polsce.

Chociaż zakaz kontaktów z innymi więźniami podyktowany względami bezpieczeństwa i ochrony lub będący wynikiem kary dyscyplinarnej, może w pewnych okolicznościach być uzasadniony, osadzenie w pojedynczej celi, nawet w przypadku gdy wiąże się z relatywną izolacją, nie może być stosowane wobec więźnia przez czas nieokreślony. Należy poszukiwać rozwiązań alternatywnych do celi izolacyjnej dla osób uznanych za niebezpieczne, których osadzenie w zwykłych jednostkach penitencjarnych w warunkach zwykłego rygoru jest niewłaściwe - Piechowicz v. Polsce.

mitet Ministrów w dniu 11 stycznia 2006 r.), http://www.bip.sw.gov.pl/SiteCollectionDocuments/ CZSW/prawaczl/document.pdf (dostęp: 30.01.2017).

3 Wyroki przeciwko Polsce: Piechowicz v. Polsce — skarga nr 20071/07; Horych v. Polsce — skarga nr 13621/08; Karykowski v. Polsce — skarga nr 653/12; Prus v. Polsce — skarga nr 5136/11; Romaniuk v. Polsce — skarga nr 59285/12; Paluch v. Polsce — skarga nr 57292/12; Świderski v. Polsce - skarga nr 5532/10. Wszystkie orzeczenia wraz z uzasadnieniami dostępne są na stronie internetowej Ministerstwa Sprawiedliwości — https://bip.ms.gov.pl/pl/prawa-czlowieka/ europejski-trybunal-praw-czlowieka/orzecznictwo-europejskiego-trybunalu-praw-czlowieka/ (dostęp: 30.01.2017).

4 W. Brzozowski, Postępowanie ze sprawcami niebezpiecznymi - główne wątpliwości konstytucyjne, „Przegląd Legislacyjny” 2015, nr 4, s. 25 n.

5 E. Januszkiewicz, Warunki odbywania kary pozbawienia wolności przez skazanych niebezpiecznych oraz skazanych wywodzacych się ze struktur przestępczości zorganizowanej, „Przegląd Więziennictwa Polskiego” 2014, nr 84, s. 98-99; oraz M. Niełaczna, „Człowiek w akwarium” - postępowanie z więżniami ,niebezpiecznymi” w oddziałach o specjalnych zabezpieczeniach, „Archiwum Kryminologii” 2014, nr 36, s. 163-170. 
w celu uniknięcia ryzyka arbitralności należy podać istotne powody przedłużenia długotrwałego okresu izolacji. Decyzja w przedmiocie utrzymania niniejszego środka powinna zatem umożliwić ustalenie, czy władze dokonały ponownej oceny, biorąc pod uwagę wszelkie zmiany w okolicznościach, sytuacji skarżącego oraz jego zachowaniu. Uzasadnienie powinno być coraz bardziej szczegółowe wraz z upływem czasu — Piechowicz v. Polsce.

Trybunał przypomina, że wszelkie formy izolacji bez zapewnienia właściwej stymulacji umysłowej i fizycznej mogą w dłuższej perspektywie wywołać szkodliwe skutki powodujące pogorszenia zdolności umysłowych i umiejętności społecznych. Mając na względzie czas trwania reżimu, który został nałożony na skarżącego, oraz bardzo ograniczone możliwości poruszania się i utrzymywania kontaktów z ludźmi, Trybunał nie ma wątpliwości, że przedłużająca się izolacja musiał wywołać w nim uczucie bólu i cierpienie psychiczne - Horych v. Polsce.

Trybunał zgadza się, że przeszukanie z rozbieraniem może być niekiedy konieczne w celu zapewnienia bezpieczeństwa zakładu lub ochrony porządku i zapobiegania przestępstwom. Trybunału nie przekonuje jednak, że systematyczne, uciążliwe oraz wyjątkowo krępujące kontrole stosowane codziennie wobec skarżącego były konieczne w celu zapewnienia bezpieczeństwa w zakładzie - Horych v. Polsce.

władzom nie udało się właściwie umotywować decyzji o przedłużeniu zakwalifikowania skarżącego jako tzw. osadzonego niebezpiecznego, a procedura weryfikacji statusu tzw. osadzonego niebezpiecznego stanowiła czystą formalność i ograniczyła się do powtórzenia tych samych podstaw - Karykowski v. Polsce.

Trybunał wskazuje, że komisja, podejmując decyzję o przedłużeniu reżimu, nie przedstawiła nowego uzasadnienia. Z przedmiotowych postanowień wynika, że poza pierwotnym uzasadnieniem, które opierało się na poważnym ciężarze gatunkowym zarzuconych czynów oraz demoralizacji, władze nie znalazły innego uzasadnienia dla dalszego kwalifikowania skarżącego jako osadzonego niebezpiecznego. Trybunał wskazuje również, że w przedmiotowej sprawie władzom nie udało się właściwie umotywować zastosowania reżimu, a procedura kontroli zastosowania statusu więźnia niebezpiecznego stanowiła czystą formalność, i ograniczyła się do powołania tych samych powodów -— Romaniuk v. Polsce.

Okoliczności, na których opierały się władze, mogą uzasadniać stosowanie reżimu wobec oskarżonego przez określony czas. Nie są jednak samodzielnie wystarczające do uzasadnienia przedłużania reżimu przez tak długi czas. Wraz z upływem czasu procedura ponownego rozpatrywania statusu osadzonego „niebezpiecznego” stała się czystą formalnością, ograniczoną jedynie do wskazania czy postęp w poprawie zachowania skarżącego jest ,umiarkowany” czy „niedostateczny”. Decyzje wydane przez Komisję Penitencjarną [...] nie zawierają odpowiedniego uzasadnienia. Sądy, oddalając odwołania składane przez skarżącego, powoływały się na uzasadnienie przedstawione przez Komisję - Świderski v. Polsce.

Przedstawione fragmenty wyroków tworzą bardzo charakterystyczny obraz praktyki działania komisji penitencjarnych, lecz także obrazują kontrolę realizowaną w tym zakresie przez sądy penitencjarne. Część z krytycznych uwag, w związku z nowelizacją kodeksu karnego wykonawczego z 2015 r., zapewne zostanie wyeliminowana, co nie oznacza, że wyłaniająca się w tym wypadku li- 
nia orzecznicza nie powinna być swoistym wyznacznikiem tworzącym standard kwalifikowania i traktowania osadzonych niebezpiecznych.

III. Ustawa z dnia 10 września 2015 r. o zmianie ustawy - Kodeks karny wykonawczy wprowadziła zmiany w zakresie kwalifikowania i weryfikacji decyzji w zakresie osadzonych niebezpiecznych. Zmodyfikowane zostały przesłanki przedmiotowej decyzji, wprowadzona została nowa formuła $\mathrm{z}$ art. $88 \mathrm{~b} \S 2$ k.k.w., pozwalająca na modyfikowanie warunków odbywania kary przez osadzonych niebezpiecznych. Celem zmian, na co wskazuje uzasadnienie projektu, było:

dostosowanie prawa polskiego do wymagań wynikających z wyroków wydanych przez Europejski Trybunał Praw Człowieka w sprawach: Piechowicz przeciwko Polsce (skarga nr 20071/07) oraz Horych przeciwko Polsce (skarga nr 13621/08). [...] państwo musi zapewnić danej osobie warunki osadzenia, które nie naruszają godności ludzkiej oraz zadbać, żeby sposób i metoda wykonywania takiego środka nie naraziły jej na ból i niedogodności o natężeniu wykraczającym poza nieunikniony poziom cierpienia związany z pozbawieniem wolności, a także, mając na względzie praktyczne wymogi uwięzienia, żeby jej zdrowie i samopoczucie były odpowiednio chronione. [...] procedura nadania osadzonemu statusu „N” nie gwarantuje, że status ten jest stosowany jedynie wobec osób, które stanowią w sposób nieprzerwany poważne zagrożenie w warunkach osadzenia [...]. Ponadto, mając na uwadze brak jakichkolwiek przepisów regulujących związek między nadaniem statusu a rzeczywistym zachowaniem osoby w zakładzie penitencjarnym, ramy prawne reżimu „N" wydają się zbyt sztywne i nie uwzględniają w sposób wystarczający indywidualnych okoliczności danego więźnia. Projektowane zmiany [...] mają na celu nie tyle ingerencję w rygory określone $\mathrm{w}$ art. $88 \mathrm{~b}$ i art. $212 \mathrm{~b}$ k.k.w., ile stworzenie prawnej możliwości stopniowego łagodzenia tych rygorów, chociażby w części, zwłaszcza po wydaniu wyroku skazującego ${ }^{6}$.

Wprowadzone wskazaną ustawą zmiany należy przyjąć z zadowoleniem; jest to wyraźny krok w dobrą stronę ${ }^{7}$. Niestety, nie udało się usunąc kilku zasadniczych wątpliwości związanych z procedurą kwalifikowania do grupy osadzonych niebezpiecznych. W niektórych obszarach nowo wprowadzone regulacje dostarczają kolejnych wątpliwości. Warto w tym miejscu przyjrzeć się kliku zasadniczym kwestiom. Jednym z najbardziej problematycznych elementów konstrukcji dotyczącej osadzonych niebezpiecznych jest procedura kwalifikowania do tej grupy oraz mechanizmy weryfikacji decyzji o jej odwołaniu lub przedłużeniu. Dyskusja w tym obszarze toczy się już od wielu lat $\mathrm{i}$ - jak można zasadnie przypuszczać - nie znalazła jeszcze ostatecznego rozwiązania. W perspektywie tej dyskusji warto zastanowić się, jaki charakter prawny ma decyzja kwalifikacyjna do grupy osadzonych niebezpiecznych. Zasadnicze pytanie, jakie w tym miejscu

${ }^{6}$ Uzasadnienie. Poselski projekt ustawy o zmianie ustawy - Kodeks karny wykonawczy, druk nr 2874, http://www.sejm.gov.pl/sejm7.nsf/druk.xsp?nr=2874 (dostęp: 30.01.2017).

7 A. Sakowicz, Opinia prawna na temat poselskiego projektu ustawy o zmianie ustawy - Kodeks karny wykonawczy (druk sejmowy $n r$ 2874), http://orka.sejm.gov.pl/rexdomk7.nsf/ Opdodr?OpenPage\&nr=2874 (dostęp: 30.01.2017). 
możemy postawić, to kwestia, czy decyzja o uznaniu skazanego za stwarzającego poważne zagrożenie społeczne albo poważne zagrożenie bezpieczeństwa zakładu to to samo co decyzja klasyfikacyjna. Przy czym wprowadzone w 2015 r. nowe rozwiązania, które miały tę przestrzeń jednoznacznie uporządkować, tak naprawdę pogłębiły istniejące wątpliwości. Kolejne pytanie to kwestia wzajemnej relacji przesłanek klasyfikacji z art. 82 k.k.w. a przesłanek kwalifikowania w trybie art. 88a k.k.w. Czy nowe przesłanki to uzupełnienie tych z art. 82 k.k.w., czy też samodzielna grupa okoliczności.

Problem przesłanek kwalifikowania do grupy osadzonych niebezpiecznych już od dawna wywoływał sporo komentarzy i uwag krytycznych. Zasadniczo zarzucano im schematyczność oraz brak elastyczności, a z drugiej strony stworzenie zbyt rozległej przestrzeni interpretacyjnej analizowanej kategorii osadzonych ${ }^{8}$. Czy zatem w ramach nowego brzmienia art. 88a k.k.w. udało się te wątpliwości usunąć? Najpierw należy przyjrzeć się kategorii przesłanek związanych ze wskazanymi w art. 88a $\S 1$ pk1 k.k.w. przestępstwami. Katalog tych przestępstw nie zmienił się w porównaniu z wcześniej obowiązującą konstrukcją. Warto zwrócić uwagę, że aktualne wyliczenie tych przestępstw poprzedza stwierdzenie, że chodzi o skazanego, który popełnił przestępstwo o bardzo wysokim stopniu społecznej szkodliwości. Wydaje się, że taka formuła to zawężenie pola przedmiotowej kwalifikacji. Są to wymienione w ramach art. 88a $\S 1$ pkt 1 k.k.w. przestępstwa, lecz także inne, ze względu na posłużenie się przez ustawodawcę sformułowaniem „W szczególności”, o ile mają one bardzo wysoki stopień społecznej szkodliwości. Kodeks karny wykonawczy nie definiuje tego pojęcia ani kwantyfikatorów służących do jego oceny. Wydaje się, że jedynym dopuszczalnym rozwiązaniem jest w tym wypadku przyjęcie wskazówek zawartych w art. 115 § 2 k.k., w którym przy ocenie stopnia społecznej szkodliwości czynu, na etapie orzekania, sąd bierze pod uwagę rodzaj i charakter naruszonego dobra, rozmiary wyrządzonej lub grożącej szkody, sposób i okoliczności popełnienia czynu, wagę naruszonych przez sprawcę obowiązków, jak również postać zamiaru, motywację sprawcy, rodzaj naruszonych reguł ostrożności i stopień ich naruszenia. Taki zabieg budzi oczywiście wątpliwość w perspektywie braku bezpośredniej wskazówki co do odpowiedniego stosowania $\mathrm{w}$ toku postępowania wykonawczego tego przepisu. Jednak wobec wyraźnego przeoczenia ustawodawcy (które powinno być w tym wypadku szybko skorygowane) jest to jedyny sposób na wskazanie czytelnych ram, niezbędnych do oceny popełnionego przestępstwa.

${ }^{8}$ R. Godyla, L. Bogunia, Niektóre problemy kwalifikowania skazanych i tymczasowo aresztowanych do grupy osadzonych niebezpiecznych, [w:] Postepowanie z wybranymi grupami skazanych w polskim systemie penitencjarnym. Aspekty prawne, red. A. Kwieciński, Warszawa 2013, s. 28. T. Artaszewicz-Zawisza, Problematyka kwalifikowania osadzonych do kategorii tzw. więźniów niebezpiecznych w świetle obowiazujacego ustawodawstwa i planowanych zmian w prawie karnym wykonawczym, „Palestra” 2016, nr 3, s. 56-58. 
Nieco inny problem może rodzić się w kontekście pytania, czy przestępstwo o którym mowa w art. 88a k.k.w., może być zrealizowane także w poprzedzających dokonanie formach stadialnych, zwłaszcza w formie usiłowania? Formy stadialne stanowią wyraźne przedmiotowe rozszerzenie karalności czynu w stosunku do opisu czynu zawartego w części szczególnej ustawy karnej. W pewnym sensie czerpią one swój sens z dokonania czynu zabronionego. Zatem czy w tym przypadku możliwe jest rozciągnięcie konsekwencji prawnych także na formy stadialne? Brak w tym przypadku jednoznacznej odpowiedzi ze względu na mało precyzyjne sformułowanie analizowanego przepisu. Prymat zasady gwarancyjnej w prawie karnym powinien skłaniać nas do odrzucenia takiego rozszerzenia i ograniczenia się jedynie do dokonania. Choć nie jest to jedyna możliwa interpretacja. Wydaje się, że ustawodawca powinien to jednoznacznie rozstrzygnąć przez zastąpienie sformułowania „popełnił przestępstwo” określeniem „dokonał przestępstwa”, co eliminuje usiłowanie. Względnie, jeżeli zależy mu na wyraźnym zwiększeniu zakresu zastosowania analizowanej konstrukcji, użyć sformułowania „popełnił lub usiłował popełnić przestępstwo".

Istotna zmiana dotyczy przesłanek związanych z tzw. przestępczością zorganizowaną. Konstrukcja obowiązująca do 2015 r. raziła swoim schematyzmem, do grupy osadzonych niebezpiecznych można było zakwalifikować w zasadzie każdego skazanego za przestępstwo popełnione w zorganizowanej grupie albo związku mającym na celu popełnianie przestępstw. Jedynie w przypadku szczególnych okoliczności można było odstąpić od takiej kwalifikacji. Pewien automatyzm starej konstrukcji razić musiał w przypadku skazanych, którzy nie odgrywali istotnej roli w ramach zorganizowanej przestępczości. Wychodząc naprzeciw tych wątpliwościom, nowe rozwiązania zakładają, że do grupy osadzonych niebezpiecznych zaliczony może być zwłaszcza skazany z uwagi na jego kierowniczą lub znaczącą rolę w grupie lub związku. Komisja penitencjarna zobligowana jest każdorazowo do indywidualnej oceny, w ramach której musi ustalić w wypadku skazanego za przestępstwo popełnione w zorganizowanej grupie albo związku mających na celu popełnianie przestępstw, jak kształtuje się zagrożenie porządku prawnego, które może wyniknąć z nawiązania przez skazanego bezprawnych kontaktów z innymi członkami grupy. Chodzi zwłaszcza o zagrożenie życia lub zdrowia ludzkiego, lub czynności mających na celu ujawnienie mienia stanowiącego korzyść z popełnienia przestępstwa. Do ostatecznej oceny istotne jest także, czy inni członkowie grupy lub związku przebywają na wolności.

Warto też zastanowić się nad relacją przesłanek klasyfikacji z art. 82 k.k.w. oraz przesłanek kwalifikowania do grupy niebezpiecznych z art. 88a $\S 2$ k.k.w. Przesłanki klasyfikacji z art. 82 k.k.w. mają charakter otwarty, ze względu na posłużenie się przez ustawodawcę, w ramach zawartego w tym przepisie wyliczenia, sformułowaniem „W szczególności”. Przesłanki te są zestawem okoliczności stosowanych przez cały okres odbywania kary, także w sytuacji zakwalifikowa- 
nia do grupy osadzonych niebezpiecznych, gdyż skazany musi mieć jednocześnie ustaloną decyzję klasyfikacyjną dotyczącą rodzaju i typu zakładu karnego oraz rozstrzygniętą kwestię systemu odbywania kary. Kryteria klasyfikacji z art. 82 k.k.w. to podstawowy wyznacznik oceny skazanego. Służą one do podejmowania wobec niego decyzji klasyfikacyjnych i ich stałego weryfikowania, w myśl zasady indywidualizacji i elastycznej modyfikacji treści wykonywanej sankcji ${ }^{9}$. W tej perspektywie jeszcze bardziej wyraźny jest dwoisty charakter kwalifikacji do grupy osadzonych niebezpiecznych. Skazany przez cały okres odbywania kary musi mieć najbardziej adekwatną do jego sytuacji decyzję klasyfikacyjną, którą jedynie może uzupełniać kwalifikacja do grupy osadzonych niebezpiecznych.

Zupełnie inaczej należy traktować zestaw przesłanek kwalifikowania do grupy osadzonych niebezpiecznych, zawarty w art. 88a $\S 2$ k.k.w. Ten katalog okoliczności ma wyraźnie zamknięty charakter i stosowany może być tylko w ramach kwalifikowania do grupy osadzonych niebezpiecznych. Przy podjęciu i każdorazowej weryfikacji takiej decyzji komisja penitencjarna uwzględnia jedynie te elementy, o których stanowi wskazany przepis. Sama redakcja analizowanych przesłanek budzi jednak wątpliwości. Przesłanki te zakresowo nachodzą na przesłanki klasyfikacji, a ich prognostyczna wartość w praktyce może okazać się wątpliwa. Pamiętajmy, że komisja penitencjarna będzie mogła poruszać się wyłącznie w obrębie tych okoliczności i tylko na ich podstawie uzasadniać swoje decyzje. Oznacza to, że nie będzie wolno wnioskować w tym przypadku odnośnie do innych okoliczności niż te wymienione przez ustawodawcę.

Każdorazowym zadaniem komisji penitencjarnej będzie także precyzyjne, niebudzące wątpliwości i czytelne, także dla skazanego, uzasadnienie wydanej decyzji. Organ musi wyjaśnić, jakie elementy uznał za czynniki decydujące o kierunku oceny niebezpieczeństwa i na jakich danych i informacjach oparł swoją decyzję. Skazany raczej co do zasady będzie je kwestionować i ma do tego pełne prawo. Uzasadnienie decyzji pełnić musi funkcję perswazyjną, to znaczy przedstawiać tok rozumowania i powody podjęcia decyzji, tak aby skazany mógł przekonać się o jej słuszności, względnie lepiej przygotować się w przyszłości. Należy wyraźnie przestrzec przed niestarannie opracowanymi decyzjami. Lakoniczne czy też zdawkowe uzasadnienia, oparte na swoistym powtórzeniu przesłanek ustawowych, będą rodziły skargi do sądu penitencjarnego, a w dalszej kolejności do ETPCz.

Pewien rozdźwięk między przesłankami z art. 82 k.k.w. oraz przesłankami $\mathrm{z}$ art. $88 \mathrm{a} \S 2$ k.k.w. widać także w perspektywie kodeksowo określonych zasad kierowania w ramach decyzji klasyfikacyjnej do zakładu karnego typu zamkniętego. Przy uwzględnieniu zestawu okoliczności opisanych w art. 82 k.k.w. zgodnie z art. $88 \S 3$ k.k.w. do tego typu zakładu (przy czym bez uruchomienia dodatko-

9 J. Lachowski [w:] Kodeks karny wykonawczy. Komentarz, red. J. Lachowski, Warszawa 2016, s. 431. 
wych warunków zapewniających wzmożoną ochronę społeczeństwa i bezpieczeństwo zakładu przewidzianych dla osadzonych niebezpiecznych) kieruje się:

- skazanego za przestępstwo popełnione w zorganizowanej grupie albo związku mającym na celu popełnianie przestępstw, chyba że szczególne okoliczności przemawiają przeciwko takiemu osadzeniu, co nie dotyczy skazanych uznanych za stwarzających poważne zagrożenie społeczne albo poważne zagrożenie bezpieczeństwa zakładu,

— skazanego na karę dożywotniego pozbawienia wolności albo na karę 25 lat pozbawienia wolności,

- skazanego z niepsychotycznymi zaburzeniami psychicznymi, w tym skazanego za przestępstwo określone w art. 197-203 k.k., popełnione w związku z zaburzeniami preferencji seksualnych, lub upośledzonego umysłowo,

- skazanego objętego ochroną na mocy art. 88d albo ustawy z dnia 25 czerwca 1997 r. o świadku koronnym (Dz.U. z 2014 r. poz. 1801).

Jest to podstawowa grupa skazanych, kierowanych na mocy decyzji klasyfikacyjnej do zakładu karnego typu zamkniętego. Jeszcze ciekawsza jest druga grupa skazanych, wyodrębniona na podstawie w art. $88 \S 6$ k.k.w. Zgodnie ze wskazanym przepisem - decyzją klasyfikacyjną, opartą na art. 82 k.k.w. (podkreślmy, że nie jest to jeszcze decyzja dotycząca kwalifikacji jako niebezpieczny), do zakładu karnego typu zamkniętego może trafić — i to ze względu na zagrożenie społeczne albo zagrożenie bezpieczeństwa zakładu — także:

- skazany za przestępstwo nieumyślne, odbywający zastępczą karę pozbawienia wolności, osoba odbywająca karę aresztu oraz skazana kobieta, a także inni skazani, których właściwości i warunki osobiste, sposób życia przed popełnieniem przestępstwa, zachowanie po dokonaniu przestępstwa, negatywna ocena postawy i zachowania w areszcie śledczym, względy bezpieczeństwa zakładu albo inne szczególne okoliczności wskazują, że należy wobec nich wykonywać karę w warunkach zwiększonej izolacji i zabezpieczenia,

— skazany, który podczas pobytu w areszcie śledczym lub zakładzie karnym naruszył w poważnym stopniu dyscyplinę i porządek,

— skazany przebywający dotychczas w zakładzie karnym typu otwartego lub półotwartego, jeżeli negatywna ocena jego postawy i zachowania, a także względy bezpieczeństwa zakładu wskazują, że należy wobec niego wykonywać karę w warunkach zwiększonej izolacji i zabezpieczenia,

- skazany, który popełnił przestępstwo o znacznym stopniu społecznej szkodliwości, jeżeli jego postawa i zachowanie przemawiają za przebywaniem w zakładzie karnym typu zamkniętego.

Podkreślmy, że wszyscy wymienieni skazani trafiają do zakładu karnego typu zamkniętego na podstawie decyzji klasyfikacyjnej, wydanej na podstawie kryteriów przewidzianych w art. 82 k.k.w. i podjętej w zależności od momentu jej wydania przez sąd skazujący, sąd penitencjarny lub komisję penitencjarną. 
Wydaje się, że decyzja o uznaniu skazanego za niebezpiecznego może zapaść dopiero po ewentualnym uwzględnieniu wskazanych tutaj podstawowych możliwości związanych z osadzeniem w zakładzie karnym typu zamkniętego. Ustawodawca wyraźnie zawęża pole uruchomienia warunków zapewniających wzmożoną ochronę, czyniąc z tej procedury swoisty wyjątek. Odnośnie do zgodnego z prawem zastosowania formuły przewidzianej dla osadzonych niebezpiecznych muszą być spełnione kwalifikowane okoliczności wskazane w art. 88a k.k.w. Podkreślmy wyraźnie, że zagrożenie społeczne albo zagrożenie bezpieczeństwa zakładu muszą przyjąć rozmiar „poważnych”, zaś przestępstwo, którego dopuścił się skazany, musi wykazywać „bardzo wysoki” stopień społecznej szkodliwości Zatem okoliczności uzasadniające podjęcie decyzji o kwalifikacji do grupy osadzonych niebezpiecznych powinny zdecydowanie różnić się od tych wskazanych w art. $88 \S 3$ i 6 k.k.w., a komisja penitencjarna musi niejako uzasadnić, dlaczego podstawowy schemat jest w tym wypadku niewystarczający.

W kontekście decyzji o zakwalifikowaniu do grupy osadzonych niebezpiecznych warto także podkreślić znaczenie nowo wprowadzonej formuły z art. $88 \mathrm{~b} \S 2$ k.k.w., pozwalającej na modyfikowanie warunków odbywania kary przez osadzonych niebezpiecznych. Komisja penitencjarna uzyskuje dzięki tej nowej konstrukcji daleko idące kompetencje w zakresie indywidualnego kształtowania sytuacji prawnej skazanego. Przestrzeń ograniczeń oraz zakres wzmożonej ochrony i zabezpieczeń regulowany jest aktualnie w art. $88 \mathrm{~b} \S 1$ k.k.w. oraz art. 88c k.k.w., przy czym art. 88c k.k.w. przewiduje obligatoryjny i niepodlegający żadnej modyfikacji obowiązek stałego monitorowania osadzonych niebezpiecznych. Monitorowanie to prowadzi się w celach mieszkalnych wraz z częścią przeznaczoną do celów sanitarno-higienicznych oraz w miejscach i pomieszczeniach wyznaczonych do: pracy, nauki, przeprowadzania spacerów, widzeń, odprawiania nabożeństw, spotkań religijnych i nauczania religii oraz zajęć kulturalno-oświatowych, z zakresu kultury fizycznej i sportu. Ustawodawca przesądza także, że monitorowany obraz lub dźwięk podlega utrwalaniu.

Inaczej traktowane są okoliczności wskazane w art. 88b § 1 k.k.w. Przepis ten wymienia enumeratywnie zestaw warunków, w jakich może zostać osadzony niebezpieczny. Katalog ma charakter zamknięty, przy czym warunki te mogą być elastycznie modyfikowane. Możliwość ich indywidualnego kształtowania to wyraźna zmiana jakościowa. Komisja penitencjarna może uznać, że nie zachodzi potrzeba stosowania wszystkich warunków wskazanych w przepisie art. $88 \mathrm{~b} \S 1$ k.k.w. Oznacza to w praktyce, że komisja penitencjarna może odstąpić od stosowania jednego lub więcej z tych warunków. Decyzja w tym zakresie musi się opierać na ocenie przesłanek zawartych w art. $88 \mathrm{a} \S 2$ k.k.w. i być w perspektywie przewidzianych w tym przepisie okoliczności szczegółowo i jednoznacznie uzasadniona. Mechanizm ten może działać w obie strony, co oznacza, że komisja penitencjarna może w każdym czasie, jeżeli jest to uzasadnione okolicznościa- 
mi, przywrócić stosowanie warunków, od których odstąpiono, lub zmienić ich zakres.

Skazany, w myśl zasady podmiotowości, ma pełne prawo występowania z wnioskami do komisji penitencjarnej zarówno w zakresie decyzji co do kwalifikacji jako osadzony niebezpieczny, jak i osobno - w odniesieniu co do warunków osadzenia, może je także w trybie art. 7 k.k.w. kwestionować. Ze względu na chęć uniknięcia nadmiernej liczby wniosków (ewentualna możliwość stałego ponawiania wniosków celem zwiększenia pracy komisji penitencjarnej) w obu wskazanych sytuacjach wnioski płynące od skazanych lub ich obrońców mogą być rozpatrywane nie częściej niż raz na 3 miesiące. Ograniczenie to nie dotyczy, oczywiście, w żadnej mierze samej komisji penitencjarnej, która może podjąć takie decyzje w każdej chwili.

Podkreślić należy także, że są to dwa odrębne postępowania incydentalne. Mimo wskazania, że podstawą orzekania w obu przypadkach są przesłanki zawarte w art. 88a $\S 2$ k.k.w., nie mogą one być w pełni identycznie oceniane w obu wskazanych postępowaniach. Czym innym jest ogólna decyzja o osadzeniu w oddziale dla niebezpiecznych oraz ewentualne utrzymywanie tej kwalifikacji. Określenie szczegółowych warunków, w jakich osadzona zostanie osoba uznana za niebezpieczną, a następnie ich modyfikowanie ma już zupełnie inny charakter. Warto na to zwrócić uwagę i wyraźnie podkreślić potrzebę rozłącznego rozpatrywania obu przedmiotowych postępowań.

IV. W komentarzu do kodeksu karnego wykonawczego Z. Hołda i K. Postulski słusznie stwierdzają, że przez decyzje klasyfikacyjne należy rozumieć decyzje o skierowaniu skazanego do właściwego, pod względem rodzaju i typu, zakładu karnego oraz do określonego systemu odbywania kary, dokonywanie zaś klasyfikacji to zespół czynności, których wynikiem jest rozstrzygnięcie w formie decyzji klasyfikacyjnej ${ }^{10}$. Biorąc pod uwagę tak zakreślony zakres pojęcia „decyzja klasyfikacyjna”, możemy mieć wyraźny kłopot z umieszczeniem w tym zakresie, zasadniczo innej co do swojego prawnego charakteru, decyzji komisji penitencjarnej o uznaniu skazanego za tzw. niebezpiecznego. Pytanie, jakie zasadnie w tym miejscu można postawić, brzmi: czy w zakres pojęcia „decyzja klasyfikacyjna” wpisać możemy decyzję, o której mowa w art. 88a § 2 k.k.w.?

Niestety, odpowiedź na tak postawione pytanie nie jest jednoznaczna. Decyzja tego typu ma dla skazanego szczególnie istotne znaczenie ze względu na zakres ograniczeń, jakie są związane z takim osadzeniem. Problem polega na tym, że ustawodawca nie zdefiniował, czy oddziały dla osadzonych niebezpiecznych (ewentualnie specjalne cele przeznaczone dla tych osadzonych) są swoistym typem, czy też rodzajem zakładu karnego. Po pierwsze, należy zwrócić uwagę, że

10 Z. Hołda [w:] Z. Hołda, K. Postulski, Kodeks karny wykonawczy. Komentarz, Gdańsk 2005, s. 342-343; K. Postulski, Kodeks karny wykonawczy. Komentarz, Warszawa 2012, s. 390. 
rozwiązanie przyjęte w ramach art. 88a $\S 3$ k.k.w. jest wyraźnym wyjściem poza zakres ograniczeń składających się na kodeksowo określony typ zamknięty zakładu karnego, opisany w art. 90 k.k.w. Ustawodawca w przypadku skazanego stwarzającego poważne zagrożenie społeczne albo poważne zagrożenie bezpieczeństwa zakładu stwierdza, że osadza się go w zakładzie karnym typu zamkniętego $\mathrm{w}$ warunkach zapewniających wzmożoną ochronę społeczeństwa i bezpieczeństwo zakładu (są to dodatkowe elementy wskazane w art. 88b i 88c k.k.w.). Wskazana konstrukcja w pewnym sensie sugeruje, że mamy tu do czynienia ze swoistym podtypem (w obrębie zakładu karnego typu zamkniętego). Ustawodawca w ramach art. 70 i 71 k.k.w. nie przewiduje jednak możliwości tworzenia takich form organizacyjnych. Kodeks wymienia tylko trzy typy: zamknięty, półotwarty i otwarty. Oczywiście nowy typ mógłby stworzyć sam ustawodawca, lecz wskazane przepisy nie pozwalają na przyjęcie interpretacji, że taki zabieg został zrealizowany.

Istniejące rozwiązanie jest wadliwe także w perspektywie wyróżnianych rodzajów zakładów karnych. Konsekwentne zastosowanie art. 70 § 1 k.k.w. oznacza, że w ramach jednego oddziału dla osadzonych niebezpiecznych możemy mieć aż cztery rodzaje zakładów karnych (art. 69 k.k.w. — zakład karny dla młodocianych, zakład karny dla recydywistów penitencjarnych, zakład karny dla odbywających karę po raz pierwszy oraz zakład karny dla odbywających karę aresztu wojskowego). Trudno uznać to za sytuację zgodną z aktualnym modelem klasyfikacji skazanych, w którym jednym z podstawowych priorytetów jest zasada indywidualizacji, oparta na schemacie: odrębny typ, rodzaj zakładu karnego i system odbywania kary. Grupa osadzonych niebezpiecznych wpada w pewnym sensie do jednej, prawnie nieokreślonej w perspektywie rodzajów zakładów karnych, eklektycznej grupy skazanych. Pamiętać musimy w tym miejscu, że istniejąca struktura zakładów karnych wynika z zasady różnicowania metod oddziaływania penitencjarnego, w ramach rodzajowo wyodrębnionych kategorii skazanych. Celem grupowania poszczególnych kategorii jest potrzeba zróżnicowania schematów, metod i środków oddziaływania w celu elastycznego i zindywidualizowanego postępowania z osadzonymi ${ }^{11}$. Chodzi o racjonalne kształtowanie środowiska więziennego, które będzie tworzyć przestrzeń do realizacji celów i zadań stawianych przed karą pozbawienia wolności. Trafnie stwierdza T. Szymanowski, że istniejące rodzaje zakładów karnych nie wyczerpują wszystkich możliwości dalszej indywidualizacji, co więcej — na podstawie art. 71 k.k.w. Minister Sprawiedliwości w drodze rozporządzenia może tworzyć, zgodnie z ustalonymi w k.k.w. celami wykonywania kary i ustalonymi zasadami klasyfikacji, nowe rodzaje zakładów karnych i systemy odbywania kary. Zakłady karne mogą być tworzone (art. $72 \S 3$ k.k.w.) jako samodzielne zakłady, lecz także jako wyodrębnione oddziały zakładów karnych

11 S. Pawela, Kodeks karny wykonawczy. Praktyczny komentarz, Warszawa 1999, s. 219. 
i aresztów śledczych, ze wspólną bądź wydzielona administracją ${ }^{12}$. Znaczenie podziału zakładów karnych na poszczególne ich rodzaje podkreśla S. Lelental, który stwierdza, że podział ten odpowiada istocie i celom klasyfikacji skazanych. Autor ten zwraca też uwagę na normę zawartą w art. 87 § 4 k.k.w., która stanowi, że do matek pozbawionych wolności, sprawujących stałą i bezpośrednią opiekę nad dzieckiem przepisu art. 69 k.k.w. o rodzajach zakładów karnych nie stosuje się ${ }^{13}$. Ten sformułowany w kodeksie wyjątek to swoiste przyzwolenie na przemieszanie skazanych kobiet (niezależnie od tej części klasyfikacji, która dotyczy rodzajów zakładów karnych) w ramach organizowanych przy wskazanych zakładach karnych domach dla matki i dziecka. Zatem ustawodawca dostrzega, że taka sytuacja nie powinna mieć miejsca i dlatego, na zasadzie wyjątku, odrębną, kodeksową normą zezwala na taką praktykę. Takiej regulacji niestety nie ma w kodeksie karnym wykonawczym w odniesieniu do osadzonych niebezpiecznych. Osobne pytanie, które tutaj się nasuwa, to kwestia, czy przy tym zakresie ograniczeń, w przeciwieństwie do matek, które zyskują bardziej uprzywilejowaną pozycję, taki wyjątek w ogóle byłby dopuszczalny. Podkreślmy, że w wypadku osadzonych niebezpiecznych, mimo wyraźnego faktycznego wyodrębnienia organizacyjnego, nie doszło niestety do prawnego i formalnego usankcjonowania tego wyodrębnienia. Problem ten nie jest jedynie kategorią porządkującą strukturę systemu penitencjarnego; nade wszystko wywołuje problemy w zakresie procedury klasyfikacyjnej. Wydaje się, że decyzja o tak daleko zakrojonej ingerencji w sferę praw i wolności osadzonego nie powinna budzić żadnych wątpliwości. Niestety, w praktyce jest zupełnie inaczej, czego najlepszym dowodem są liczne skargi osadzonych do ETPCz.

Przykładem zamieszania, jakie powstaje w konsekwencji przyjętych rozwiązań, jest sytuacja przeniesienia skazanego z zakładu karnego typu otwartego do oddziału dla osadzonych niebezpiecznych. Przeniesienie takie wymaga najpierw zmiany decyzji klasyfikacyjnej w trybie art. 76 § 1 pkt 1 k.k.w. i art. 74 k.k.w., tak aby skazany mógł trafić do zakładu karnego typu zamkniętego, a następnie kolejnej decyzji o osadzeniu w oddziale lub celi dla osadzonego niebezpiecznego w trybie art. $76 \S$ pkt 7 k.k.w., w tym przypadku z dodatkowym obowiązkiem poinformowania o tym fakcie sędziego penitencjarnego (art. 88a $§ 4$ k.k.w.). Zatem do skutecznego osadzenia skazanego w warunkach wskazanych w art. $88 \mathrm{~b}$ i 88c k.k.w. potrzebne są dwie odrębne decyzje. Aby osadzony mógł być poddany takiemu reżimowi w sposób zgodny z prawem, musi mieć najpierw zmienioną decyzję klasyfikacyjną w odniesieniu do wskazanych w art. 70 typów zakładów karnych. Dopiero po tym można rozważać wzmożoną ochronę w ramach typu zamkniętego, o której mowa w art. 88a $\S 3$ k.k.w. Brak rozstrzygnięcia kodeksowego co do charakteru prawnego kwalifikacji do grupy osadzonych niebezpiecznych w zakresie

12 T. Szymanowski, Prawo karne wykonawcze z elementami polityki karnej i penitencjarnej, Warszawa 2017, s. 264.

13 S. Lelental, Kodeks karny wykonawczy. Komentarz, Warszawa 2014, s. 245-246. 
ustalenia, jaki tu mamy rodzaj i typ jednostki penitencjarnej, doprowadza przy pełnym uwzględnieniu istniejących regulacji do wskazanych trudności i formalnych problemów w obrębie przedmiotowych decyzji.

Wskazaną niekonsekwencję ustawodawcy i jej praktyczne skutki widać jeszcze bardziej, gdy decyzja klasyfikacyjna jest wynikiem zastosowania art. 62 k.k. - klasyfikacja w ramach wyroku skazującego wydana przez sąd meriti. Jeżeli nie zachodzą warunki opisane w art. $74 \S 1$ k.k.w., to decyzję w tym zakresie, zmieniającą wcześniejsze wskazania co do klasyfikacji, podjąć może jedynie sąd penitencjarny. Jednocześnie ten sam sąd penitencjarny, ze względu na treść art. 76 $\S 1$ pkt 7 k.k.w., nie może wydać decyzji o osadzeniu skazanego w oddziale dla niebezpiecznych. Jest to wyłączna kompetencja komisji penitencjarnej, która musi co najmniej raz na 3 miesiące ją weryfikować. Decyzji skierowania do grupy osadzonych niebezpiecznych nie może wydać także sąd skazujący, choć razem z sądem penitencjarnym oraz komisją penitencjarną są organami klasyfikacyjnymi (bo taki rodzaj ani typ zakładu karnego formalnie nie istnieje w kodeksie karnym wykonawczym). Oznacza to w praktyce, że istniejące rozwiązania w zakresie kwalifikowania osadzonych jako niebezpiecznych nie mieszczą się w konstrukcji decyzji klasyfikacyjnej, mimo że decyzja ta bardzo mocno związana jest z klasyfikacją. Problemów w tym zakresie jest zbyt wiele, aby przechodzić nad nimi do porządku dziennego.

Zaskakiwać musi bardzo dziwne i nierównoprawne ukształtowanie zakresu kompetencji trzech ustawowo wskazanych organów klasyfikacji — sądu skazującego, sądu penitencjarnego i komisji penitencjarnej. Jeszcze dalej idącym dowodem zamieszania, chyba nie do końca świadomego, jest szczególny i jedyny przypadek, w którym sąd penitencjarny mógłby jednak wydać decyzję dotyczącą osadzonego niebezpiecznego. Chodzi o kontrolę w trybie art. 7 k.k.w. decyzji komisji penitencjarnej. W sytuacji np. podniesienia przez osadzonego zarzutu niezgodności z prawem decyzji kierującej do grupy osadzonych niebezpiecznych lub jakiegoś fragmentu treści tego typu decyzji sąd penitencjarny, zgodnie z art. 7 $\S 5$ k.k.w., może utrzymać taką decyzję w mocy, uchylić ją — i te dwie sytuacje nie budzą wątpliwości - lecz sąd może także zmienić zaskarżoną decyzję, tym samym merytorycznie zastępując komisję penitencjarną. Co więcej, na takie postanowienie sądu penitencjarnego nie przysługuje zażalenie. Zatem naturalnym pytaniem, jakie tu powstaje, jest kwestia, jak taką formę rozstrzygnięcia będzie mógł zakwestionować osadzony i czy skoro wydał ją sąd penitencjarny, a nie komisja penitencjarna, to czy należy i można ją co 3 miesiące weryfikować, i w jakim trybie? Te pytania i wątpliwości niestety mnożą się, a sytuacja osadzonych niebezpiecznych, ze względu na zakres ingerencji, wymaga wręcz drobiazgowej precyzji, której istniejącym przepisom wyraźnie brakuje.

W perspektywie de lege lata warto rozważyć usunięcie istniejących wątpliwości. Zmiany mogłyby odnosić się do wprowadzenia w ramach art. 69 k.k.w. no- 
wego rodzaju zakładu karnego - dla osadzonych niebezpiecznych. Taki zakład powinien być przeznaczony dla wszystkich skazanych spełniających przesłanki zakwalifikowania jako niebezpieczni, i to niezależnie od ich wieku (rozwiązywałoby to problem skazanych młodocianych w zakresie rodzaju zakładu karnego i było neutralne w perspektywie systemów odbywania kary). Jednocześnie, w ramach art. 70 k.k.w., powinien zostać stworzony kolejny typ: zakład karny typu zamkniętego o podwyższonym poziomie zabezpieczeń, przy czym ta forma organizacyjna powinna być zastrzeżona tylko dla zakładu karnego dla niebezpiecznych. Propozycja usuwa istniejące wątpliwości i powoduje, że proces ten w pełni staje się częścią klasyfikacji skazanych ${ }^{14}$.

\section{Dangerous prisoners. \\ Selection procedure, verification and the scope of restrictions}

\section{Summary}

The article focuses on new solutions in the Executive Penal Code relating to the procedure for qualifying for a group of dangerous prisoners and the range associated with the qualification constraints and their possible modification. Prisoners posing a serious social threat or a serious risk to the safety of penitentiary institutions are a special group of people criminally isolated. They are aggressive and deeply demoralized prisoners, the most dangerous perpetrators of crime and the persons directly involved, and often holding managerial positions, within the framework of organized crime. In practice of the functioning of the penitentiary they are a real threat to the proper functioning and security of prisons.

Keywords: dangerous prisoner, imprisonment, classification of convicts.

14 T. Kalisz, Decyzja klasyfikacyjna. Charakter prawny oraz tryby kontroli i weryfikacji, „Nowa Kodyfikacja Prawa Karnego” 36, red. T. Kalisz, Wrocław 2015, s. 75. 